\author{
Justyna Nawrot \\ University of Gdańsk \\ j.nawrot@prawo.univ.gda.pl \\ ORCID 0000-0003-2538-0524 \\ https://doi.org/10.26881/gsp.2019.3.12
}

\title{
MARITIME SAFETY MODEL ACCORDING TO REGULATIONS IN ANCIENT LAW ${ }^{1}$
}

When Noah began building the Ark, he learned the principles of its construction from the Creator himself. ${ }^{2}$ Construction of the Ark would allow him to oppose the element that is the sea and thus save the human race. Modern principles of safe shipbuilding are, obviously, far more complex than the guidelines that Noah obtained from the Creator. However, as the research conducted by scientists today proves, the Ark built by Noah corresponded to three basic parameters of safe ship construction currently required in the field of ship's structural integrity, stability and seaworthiness; what is more, construction of the Ark is in line with the modern construction standards for the largest cargo vessels. ${ }^{3}$ It seems that the Creator knew what he was doing.

\footnotetext{
1 The conducted research was funded by National Science Centre, Poland, under the contract UMO2016/23/D/HS5/02447 Maritime safety legal system.

2 Genesis 6.14-20 (all quotations come from the English Standard Version of the Bible available at https://www.biblegateway.com/): “Make yourself an ark of gopher wood. Make rooms in the ark, and cover it inside and out with pitch. This is how you are to make it: the length of the ark 300 cubits, its breadth 50 cubits, and its height 30 cubits. Make a roof for the ark, and finish it to a cubit above, and set the door of the ark in its side. Make it with lower, second, and third decks." Regardless of whether one treats the biblical statement as true or as a legend, this description is one of the first concerning construction of a ship. Even in the nineteenth century, the founding of Noah's Ark was dated to approx. $2300 \mathrm{BC}$. It resulted from the dating relative to the creation of the world, based on the sum of lifespans of the Old Testament prophets.

3 This is evidenced by South Korean scientists specializing in the construction of ships in a scientific study: Hond [et al.] (1994). It should be emphasized that the purpose of constructing Noah's ark was not shipping understood as carriage/transportation of goods by sea from one place to another, but rather remaining on the surface of water and opposing its element.
} 
The perils of the sea $a^{4}$ are the cause and the unifying force of the entire human output regarding the principles of safe navigation. Since the dawn of time, the human has been navigating, first on rivers and then at sea, near the coasts and then transoceanically. Interest in the safe construction of ships is visible in one of the oldest monuments of law, the Code of Hammurabi, which referred to certain standards regarding the construction of the ship and the responsibility of the builder (Gaca, 2016, 21 and the quoted references). ${ }^{5}$ The interest in safe navigation was due to the growing importance of sea trade in the economies of ancient empires. This economic aspect set the direction which the development of maritime law would follow for many millennia. Mercantile axiology and profit have become a determinant of the evolution of maritime law institutions since the earliest times; in consequence, ship's safety issues have turned out to be, in a sense, a tool for economic goals, not the main purpose of maritime law. Already at the beginning of considerations on the history of maritime safety, this difference in the axiology of the development of private sea law regulations should be noted, whereby the underlying premise of the regulations affecting ship's safety level was the willingness to reduce the risks of sea travel and maritime public law which aimed at the protection of universal values, the most important of which was and is the protection of human life.

For this reason, the ship continued to be the key focus of maritime law, being a specific link between civil (commercial) maritime law and the much younger public maritime law. Therefore, the sea itself was not the subject of maritime law regulations; it was the ship as a tool for navigation. As a subject regulated by law, the sea appears for the first time in an area defined as the Law of the Sea, which constitutes a part of public international law. The birth of the Law of the

4 The English concept of perils of the sea, referred to in the Polish doctrine as "the hazards of the sea", is still an important concept for maritime insurance law. This concept initially referred to the extraordinary forces of nature that seafarers were forced to face while navigating, and included events occurring during the sea voyage referred to as acts of God, meaning only those accidents or losses that happened in situations beyond human control, as a result of natural threats of unprecedented, extraordinary strength. Over time, this concept was adopted by maritime insurance law and, as part of the concept of covering marine risks, extended also to other events related to the possibility of a fire, explosion, pirates, privateers or the need to jettison. In other words, the concept of maritime perils was defined to cover a number of marine risks related to maritime dangers and those related to shipping. See e.g. Łopuski (1982), 95.

5 In relevant Polish literature, however, there is a divergence of views as to whether the provisions of the Code of Hammurabi applied exclusively to river navigation or to sea navigation as well. The former view is espoused by Stanisław Płodzień, while Stanisław Matysik argues for the latter. See Płodzien (1961), 24-25. The author explains that the application of the provisions of the Code of Hammurabi to river navigation results directly from paragraph 240 , which in the Polish version does not contain the concept of river navigation, although it explicitly refers to it. This interpretation is also supported by the geographical location of ancient Mesopotamia, i.e. between the Euphrates and the Tigris. The name Mesopotamia itself, in Greek, meant "the land between two rivers". The other possibility, concerning the application of the Code in maritime shipping, is adopted by S. Matysik in numerous publications: e.g. Matysik (1959), 15; Matysik (1971), 24. 
Sea should be dated to the seventeenth century, ${ }^{6}$ when the issues of state power and freedom of navigation became the subject of regulations and legal treatises. ${ }^{7}$ Until then, however, common maritime law was a kind of ius gentium, the law of the seas, which because of its similarities was common to all the people of the sea. It was not until the eighteenth and nineteenth centuries that these common sea customs, similar in their foundations, lost their significance. The particular interests of states promoting their own legal solutions and the jurisprudence of national courts weakened the significance of this common "law of the seas" in favour of national orders. It was also connected with the struggly for naval dominance, including the domination of a specific legal order (jurisdiction).

Currently, it is assumed that maritime law covers all legal norms regulating social relations connected with human activity consisting in the use of the sea (Łopuski, 1996, 24). In this approach, the fundamental criterion defining the maritime law framework is the subject and not the nature of the regulation. The scope of maritime law has continuously expanded, and the basic factor causing it to change is the progress of technology, which makes new ways of using the sea possible. Initially, marine human activity was limited to using the ship as a vehi-

\footnotetext{
6 The most important treatises include: Mare liberum by Dutchman Hugo Grotius, published in 1609 (which in fact was a chapter of De Jure Praedae, a treatise discovered in 1865) and Mare Clausum, seu de dominio maris libri duo by the English jurist Jan Selden, published in 1635. Both treatises differently defined the principles of navigation on the seas and the scope of coastal states' power. The treatise of the Scottish lawyer William Wellwood, Abridgment of All Sea-lawes, first published in 1613 in English, and then in 1615 in Latin under the title De Dominio Maris, is also worth mentioning here. Both Selden and Wellwood were in favour of the concept of the mare clausum, where one country might have the right to rule over and control it, as in the case of land. Hugo Grotius never argued with Selden, but he made some polemical assertions in relation to the ideas of Wellwood in the aforementioned De jure Praedae treatise. In 1702, Cornelius van Bynkershoeck, a Dutch lawyer, formulated a compromise theory in his work De Dominio Maris Disertatio, according to which a state had the right to control the part of the sea that was directly related to the protection of its coast. This principle is called in the English literature the cannonshot rule, because it defined the range of domination and control of the coastal state at the firing distance of a cannonball. Such a distance was adopted in many national regulations, e.g. in Russia in 1787, Tuscany in 1778, Genoa in 1779 and Venice in 1779. This distance, changing with the development of military technology, was defined as 3 miles from the coast in 1782 by the Neapolitan Ferdinando Galiani in the treatise $D e^{\prime}$ doveri dei principi neutrali verso i principi guerreggianti e di questo verso i neutrali, and it remained widely accepted for over 100 years. For more on this subject see: Treves (2015), 3-7. National regulations in this context are also mentioned by Azuni (2015), $203 \mathrm{ff} .$, who also cites an anonymous verse regarding the regulation of cannonshot rule: "Far as the sovereign can defend his way, extends his empire o'er the wat'ry way; the shot sent thundering to the liquid plain, assigns the limits of his just domain." Azuni (2015), 216 also refers to Polish involvement in the politics of dominance in the Baltic, mentioning that in 1637 Polish king entered into a dispute with the Danish ruler over a ship sent by the Polish king to Gdansk to collect a new tax. The ship was stopped by the Danish ruler. It was probably an attempt by king Władysław IV Waza to impose a sea duty by on the inhabitants of Gdańsk, while the Danish king, Christian IV came to their aid by seizing the Polish ship. The exchange of letters between the Polish and the Danish ruler, which Azuni decribed, probably means the correspondence written by the royal canon Ludwig Crusius or Jerzy Ossoliński. See more: Kotarski (1970), 258-276.

7 Until the seventeenth century, the "stronger wins" rule was decisive.
} 
cle for transporting people and goods, but with the technological development, maritime law began to include distinct modes of exploitation of the, such as deepsea mining, construction of wind farms, etc.

\section{Maritime safety law with respect to development of maritime law}

Given that modern maritime law is rooted in the customs and collections of laws, as well as in the continuity of many maritime law institutions and historical concepts which predominated in that domain, one necessarily has to consider a broader background of historical regulations governing maritime safety. The words of G.H. Robinson, an outstanding American lawyer of the early twentieth century, are worth quoting here: "[Maritime law is] one of the oldest and most historic branches of our jurisprudence (...)" (oquoted after: Libera, 1957, 12-13).

\subsection{Ancient regulations on maritime safety}

Approximately in the fourth century BC, the island of Rhodes gained increasing significance on the map of maritime trade, owing to its location. A little earlier, the first known maritime law institutions had developed in Athens, a port city with a perfect location and merchant traditions. Those were the Athenians who have been credited with improving the maritime loan institution ${ }^{8}$ as a special type of loan, the repayment of which was only obligatory when the sea voyage was successfully completed. It was also in Athens where the dikai emporikai, special maritime commercial courts, operated. ${ }^{9}$

If we analyse the essence of Lex Rhodia de iactu, the first regulation regarding the compensation for merchandise thrown overboard at sea to lighten the ship, it may at first glance appear to have a purely economic purpose, in that the loss is distributed. However, one cannot help noticing that in its very essence the regulation focused on the safety of the ship (see, for example Koziński, 2001, 88).

\footnotetext{
8 The Phoenicians, who ruled over the Mediterranean already around the sixth century BC, are said to have coined the concept of a maritime loan. Numerous sources speak of the Phoenician ascendancy in that region, which lasted for nearly 1,000 years. They are also considered by a number of legal historians to have been the creators of the first solutions regarding the use of the sea, and thus the regulations that we would define today as the law of the sea within international public law. See Potter (1924), 11; Azuni (2015), 25.

9 Their jurisdiction essentially covered commercial issues related to the enforcement of maritime claims, as one would name them today. Proceedings before the Athenian Courts involved, apart from the need to take into account the speed of proceedings in maritime affairs, the necessity to include ethical standards. See: Cohen (1973), 21. In addition, these courts decided in matters not only between Athenians, but also in cases involving foreigners. In a E. Cohen's monograph devoted to the institutions of Athenian maritime courts, they are referred to as "supranational", but the meaning of this term as used in the monograph differs from the modern concept of supranationalism. The author also outlines the requisites for the admission of foreigners to the Athenian Courts; for instance, the claim had to have resulted from a contract concluded in writing. In consequence, the jurisdiction of the Athenian maritime courts is defined by the author as a jurisdiction limited by ratione rerum as opposed to ratione personarum. See Cohen (1973), 89.
} 
The practice of discarding goods which were most often a part of ship's cargo (or ship's equipment), was probably used since shipping began. The law of jettison was therefore nothing more than a catalogue of customs commonly used in the Mediterranean which, during the heyday of the island of Rhodes, i.e. between 304 and 168 BC, began to be called the Rhodian Sea Law (Płodzień, 1961, 23). ${ }^{10}$ The principle of dividing the losses arising from throwing goods overboard between all persons involved in the sea voyage was subsequently adapted by Roman lawyers. Although there is no evidence of a formal reception of the Rhodian Law of Jettison into Roman law (Płodzien, 1961, 40), the Digest demonstrates that Justinian's compilers were able to collate the cases of goods thrown overboard in the form of De lege Rhodia de iactu, a title in Book XIV of the Digest.

The fact that the birth of the first known maritime law institution is attributed to ancient Greece is not surprising. Even a cursory knowledge of Greek mythology suffices to realize that the sea and its element was an important component of Greek civilization in antiquity, as evidenced by the adventures of Odysseus, the quest for the Golden Fleece and the flight of Icarus and Daedalus over the

10 The author provides numerous examples of the use of jettison in antiquity, referring for instance to the biblical account of throwing Jonah overboard, preceded by a parley of seamen, and the act of throwing some of the goods overboard to lighten the ship when the storm hit. The author also quotes Cicero's analysis of the comments made by Hecato of Rhodes, who wondered what should be thrown into the sea in times of danger: "shall it be a valuable horse or a slave of no value" (English translation is taken from The ethical writings Cicero, translated by Andrew P. Peabody $(1887,86)$. These considerations, of course, would now have no justification, but at the time a slave was treated as an element of the cargo. Unfortunately, they remained valid for a long time, well into the modern period, as evidenced by the famous 1831 ruling in Gregson v. Gilbert, made by the renowned British lawyer, Lord Mansfield. The action concerned throwing 132 slaves overboard the Zong ship in order to lighten the vessel and save the shrinking supplies of drinking water, and consisting essentially in a dispute between the owners of the ship and the insurer. The owners demanded that the losses due to jettisoning of the slaves should be settled according to the rules originating from the institution of the Rhodian Law of Jettison (institution of maritime law, currently known as the general average); the insurer refused to pay compensation, having doubts whether there were grounds to invoke general average. The matter - shocking though it may seem today - was considered at the time mainly in economic terms. If general average had been deemed to apply, and the jettison of part of the cargo found necessary to rescue a ship, the crew and other cargo, then ship owners would have had to be compensated for each slave. If, on the other hand, it had been determined that there were no grounds to invoke general average, the owner had no right to compensation. It should be added that the insurance policy did not cover losses in cargo arising from natural causes, which in the case of cargo consisting of slaves meant losses resulting from diseases or death of slaves on board, but included losses resulting from the use of general average and thus the throwing of the cargo (slaves) overboard to rescue the ship. The adoption of such an "economic" perspective, whereby slaves were considered cargo, also meant that in the first place women and children were thrown overboard as items of lower economic value than men. In the case reports, one can even find a sentence that draws on Hecato's observation cited in antiquity by Cicero; uttered by one of the judges, it states that it is shocking to treat throwing slaves and horses overboard equally. Pragmatism led people to approach the Zong ship as an insurance case, perhaps atypical, in which the main subject of analysis was to examine the existence of circumstances justifying the use of general average. The case was discussed in an interesting way in Polish literature by Zajadło (2017), 52-64. 
Mediterranean coast - all that attest to the great importance of the sea as a route as well as the awareness of its dangers in the Greek world.

It is also in antiquity that one can find the first mention of the institution currently referred to as an "open, safe port", enabling a ship at risk of sinking at sea to enter any nearest port. ${ }^{11}$

The Roman adoption of the Rhodian Law of Jettison strengthened this institution of maritime law and allows us today to find its roots in ancient Greece. The Romans were greatly impressed not only by the Greek culture and philosophy ${ }^{12}$ but also by the acquis of maritime law and the ability to deal with the perils of the sea, including pirates who at that time plagued the Mediterranean. The Roman encounter with the Rhodians in the period of the expansion of the Roman Empire around the first century BC resulted in the acquisition and adaptation of the maritime law of ancient Greece by the former.

The Rhodian Law of Jettison as mentioned above was adopted by the Roman lawyers, as evidenced by the inclusion of regulations regarding the effects of throwing the goods overboard in Justinian's Digest (D. 14.2). The vast majority of the doctrine indicates that the source of claims for the compensation of loss resulting from throwing the goods overboard lay in the construction of a community of danger (Lat. communio). Such a community of danger, according to S. Płodzien (1961, 140 and the abundant sources cited there), existed between all persons interested in the cargo and the ship, and concerned the possibility of compensating for the losses suffered in common interest. The author does not unequivocally subscribe to such an interpretation of incorporation of the Rhodian Law of Jettison into Roman law, as it did not derive from the Roman lease agreement, but from the the Greek community of danger. Such a community, found in Greek sources, was not a partnership agreement in the strict sense as its essence consisted in factual activity which made its members participate in the profits and losses resulting from one or many maritime undertakings. Nevertheless, the prevalent view argued in the literature is that despite the differences in the scope of application of the Greek and Roman regulations concerning the obligation to jointly compensate for the loss resulting from jettison, the correct basis for joint compensation for jettison-related loss in Roman law is based on fairness (Lat.

11 According to S. Matysik, who in turn relies on Pardessus' account, those were Egyptian ports which foreign ships driven by a storm could enter after making a promise that they were there due to force majeure conditions. See Matysik (1950b), 31.

12 J.M. Kelly points out that while the military and political conquest of Greece by the Romans is a fact, something in the nature of reciprocal conquest took place in the sphere of the intellect. Kelly does not analyse Greek legacy in the field of maritime law, but indicates that law as a science did not exist in ancient Greece. It was rather perceived in terms of a theoretical domain or a rhetorical contest. Roman adoption of certain solutions in the field of maritime affairs is therefore atypical and also proves that Greek solutions in this field should be considered extremely practical. See Kelly (2006), 68-70. About Romans learning the solutions in the field of maritime law from Greek law see Osuchowski (1951). 
aequitas) and in a certain community of danger (Lat. communis periculi), which has its counterpart in the Greek construction of the community of danger. It should be noted, however, that Roman lawyers would employ compensation for losses in conjuction with complaints arising under a lease contract (Płodzień, 1961, 50).

Roman law is presumed to be one of the three pillars of Latin civilization, alongside Greek philosophy and the Christian religion. Its achievements, also in the field of maritime law, are significant, although they mainly include civil law regulations regarding trade rules. Nevertheless, the singular trait of Roman legislation is that the effects of events or acts causing loss were regulated in a relatively detailed manner. Roman law also had provisions applicable to ship collisions, namely the lex Aquilia, enacted through advocacy of Aquilius, the tribune of the Plebs, which defined the effects of damage to objects and stipulating liability ${ }^{13}$ of the ship culpable of negligence. This and other general principles of liability are certainly relevant to the issue of navigation, just as Roman law greatly influenced the determination of the degree of guilt, the structure of contracts, etc. Nevertheless, the Roman legacy dedicated to shipping was relatively modest. Justinian's Digest regulated the Rhodian Law of Jettison (Lat. Rhodia de iactu), the maritime loan (Lat. foenus nauticum), the liability of the ship owner for the accepted load (Lat. receptum nautarum ${ }^{14}$ ), and the law of the coastal state (Lat. naufragium) (Łopuski, 1996, 71). ${ }^{15}$ In the later Byzantine codifications, maritime law was regulated in the Ecloga, the codification of Leo III the Isaurian and his son Constantine; also Book LIII of Loe VI's Basilica was dedicated to maritime law. ${ }^{16}$ Their content modified the provisions of Justinian's code, which seems relatively obvious when

13 This concept of ship denotes persons who are liable in connection with its operation. Initially, the trend referred to as "ship personification" meant identifying the ship's liability with the ship's owner. However, with the separation of the owner's function from the person actually operating the ship, the concept of "liability of the ship" referred to everyone who takes over responsibility for the operation of the ship, i.e. a carrier who is not the ship's owner.

14 It concerned the carrier's liability for the cargo accepted on board and was similar to the objective liability based on the principle of risk.

15 However, one should bear in mind that the basic problem that Roman law posited in connection with the saving of property was the issue of ownership of things thrown to the seashore, and adopted regulations aimed at protecting survivors and their property. See Adamczak (1981), 23.

16 This book consisted of three parts. The first was a kind of introduction, the second consisted of 19 articles, as many as seven of which concerned the distribution of remuneration between the captain and other crew members, among which the helmsman, the carpenter and the cook were specified. The next eight articles concerned the accommodation of merchants and passengers. The remaining articles discussed the principles of financial settlements related to the carriage of cargo, maritime loan and shares. The third part was the longest and contained provisions for various events that could take place during the sea voyage. It regulated the issues of discipline on board, penalties for assassination or theft on board, goods deposit, loans granted, rescue issues, transactions made during travel, the behaviour of seafarers, and jettisoning. A detailed analysis is carried out by Khalilieh (2006), 10-14. The author also describes the influence of Islamic law on admiralty law. Matysik (1950b), 11 writes about Byzantine achievements in the field of maritime law. 
one takes into account the unfavourable circumstances of sailing in that turbulent period, which was replete with wars, disputes and uncertainty.

The Rhodian Sea Law adopted by the Romans also referred to the issue of seamen. Chapters 5 to 7 of the aforementioned codification of maritime law contained provisions concerning discipline on board, established the responsibility of seafarers for participation in fights, but also the liability of the ship (owner) for personal injuries sustained in connection with work on board. The subsequent chapters contained regulations resembling the modern maritime lien institution, which gives seafarers on board the possibility of satisfying claims on account of overdue remuneration from the ship (Couper, 2005, $5 \mathrm{ff}$.). It was a relatively comprehensive regulation, which can be described as the foundations of admiralty law.

To a limited extent, Roman achievements penetrated into the collections of maritime law established in the Early Middle Ages, most often in local languages, and were drawn upon at the time of great modern European codifications; they did not lead to a significant unification of solutions adopted in Europe (Łopuski, 1996, 73 ff.). Roman maritime law solutions, unlike previous maritime regulations, were not created for the use of small communities around seaports. On the contrary, the geographical expanse of the Roman Empire meant that Roman regulations on shipping were also applied across a large part of Europe. Undoubtedly, they also had an impact on the medieval collections of maritime laws, which would be compiled in Europe from the thirteenth century onwards, although the influence of the Roman law on the continental maritime law was smaller than on civil law. ${ }^{17}$ However, the very acquis of Roman law, which is a certain common reference point for European countries by virtue of similarity of the classification of norms, the conceptual framework and mechanisms of interpretation, also affected the shape of maritime law in the continental part of modern Europe. Roman law had a different influence on the Anglo-Saxon maritime law, to which it was incorporated relatively late, in the eighteenth century, through the reception of legis mercatoriae into common law. Thus, the significance of Roman law for the development of maritime law was primarily visible in its private dimension. The antique achievement with regard to maritime safety was not elaborated. It is not a coincidence that the most spectacular institution of the ancient maritime law, created by the Greeks and then adopted by the Romans, was the Law of Jettison, applicable in the situation where one already has to deal with a threat at sea caused mostly by the weather and ship overloading. These situations were frequent in antiquity, because the ships tended to carry excessive cargo and there were no effective devices to counter the perils of the sea. As an example of preventive regulations, albeit introduced to a negligible extent, one may mention

\footnotetext{
17 The private law part of maritime law shows a definite continuity of certain regulations with solutions known in ancient Greece and Rome, for example in the scope of the contract of affreightment, ship lease agreements, limitation of the carrier's liability for damage or loss of cargo, etc.
} 
a ban on sailing in the winter time, when the ship and crew were most likely to be threatened by terrible weather conditions at sea. Until recently, the view that coastal shipping declined in ancient Greece precisely because of adverse weather conditions that increased the risk of shipwreck off the coast predominated among historians. ${ }^{18}$ Recent publications, however, prove that the ban was mainly applied to the fishing fleet, and to a lesser extent to the transport of passengers and cargo (Dugan, 2015, 306). The Romans sanctioned it by introducing a ban on shipping without obtaining the so-called dimissorium, or the consent of a competent official to go out to sea (for more details, see Shirop, Linden, 2005; Arnaud, 2016, 142). The calendars concerning the prohibition of shipping in specific seasons, used as a way to prevent marine accidents caused by the sea element were also used in the Middle Ages. Similar prohibitions were in force in medieval maritime law collections, in the Rolls of Oléron, in the maritime regulations of port cities such as Hamburg, Lubeck, in the Hanseatic recesses or in Venetian law. ${ }^{19}$

Little is known about the required qualifications of the crew of ships in antiquity. The analysis of historical sources proves, however, that certain requirements were imposed on them, such as knowledge of the ship's structure, navigation using the stars, the ability to tell signs of weather changes at sea and recognition of changes at sea according to the behaviour of marine animals. ${ }^{20}$

\section{Conclusions}

Currently, maritime safety has a much broader scope than in the historical approach described above. Legal regulations do not only govern the safety of the ship, the people and the cargo, but also the safety of the marine environment, which is reflected in the rapid development of legislation on the protection of the

\footnotetext{
18 On the other hand, O. Tamuz claims that it was high seas navigation rather than inshore navigation which was practised throughout the year, also in winter. He cites documents proving that ships travelled in the winter time between e.g. the island of Rhodes and the port of Alexandria, and therefore at a considerable distance from the coast. This was due to the lower risk of the ship running aground during a strong storm or poor visibility of the stars. Cf. Tamuz (2005), $145 \mathrm{ff}$. Matysik (1950b), 23 points out that "sailors had known for only a few centuries that it is better to travel far away from land during a storm." However, as indicated above, this is contradicted by the research carried out by $\mathrm{O}$. Tamuz on the prohibition of coastal shipping with the possibility of practicing seafaring in antiquity. Matysik (1950b), 26 also mentions the calendars stating prohibited shipping periods in ancient Greece and Rome, whilst highlighting - as most maritime law historians do - their preventive nature in the field of maritime safety.

19 Prohibited shipping periods were differently defined in various regulations, but all pertained to periods of bad weather, stormy periods or sea icing (e.g. in the Baltic Sea). Matysik (1950b), 27 observes, however, that in the Middle Ages this prohibition was applied irrespective of the weather conditions, also as an instrument to outrival competition, giving an example of the prohibition on sailing used by the Hansa in the fourteenth century as a way of eliminating Portuguese and English competition.

20 Lindsay (1874), 34 emphasizes the already emerging awareness of training seafarers, not just disciplining the crew. See also in Polish literature: Matysik (1950a).
} 
marine environment, with the leading International Convention for the Prevention of Pollution from Ships (MARPOL) of 1973 together with the Protocol of 1978, and regulations on the so-called human factor, expressed in the International Safety Management code (ISM code), a part of the Safety of Life Convention 1974 (SOLAS 1974), the International Convention on Standards of Training, Certification and Watchkeeping (STCW convention) and the Maritime Labour Convention (MLC convention).

The evolutionary nature of the development of maritime safety standards presented in a chronological perspective allows one to illustrate their scope. The impact of technological development on the scope of regulations is clearly noticeable. In addition, maritime safety regulations are part of the general history of the development of state and legal concepts. Due to limited shipping, there were generally no preventive norms in the ancient period of history. Available sources show that the then maritime law institutions did not aim to limit the risk resulting from the perils of the sea, and focused on developing rules to spread the risk of sea travel. This proves the already existing awareness of the specificity of maritime law, the source of which is increased risk, particularly severe in the situation of the inability to deal with the perils of the sea. The institutions shaped at that time, such as the Law of Jettison or the maritime loan, concerned issues related to the distribution of risk between the entities involved in a sea voyage, according to the navigare necesse est philosophy. This model of regulation may be described as being stateratic, from the Latin statere, meaning balance. In this model, the adopted solutions concerning the distribution of risk between the involved entities were not only intended to provide adequate compensation for loss, but also to make all involved entities have an interest in taking actions that increase the chances of success of the sea voyage. Therefore, the search for balance did not refer only to the effects of the events causing the loss, but aimed at mobilizing all the entities involved to make an effort for the success of the enterprise. The principles of risk distribution can also be interpreted as an expression of solidarity and evidence of the existence of a community of sea people.

\section{Secondary Sources}

Adamczak, W. (1981), Instytucja ratownictwa morskiego we wspótczesnych stosunkach żeglugowych, Gdańsk.

Arnaud, P. (2016), Cities and Maritime Trade under the Roman Empire, [in:] Ch. Schäfer (ed.), Connecting the Ancient World. Mediterranean Shipping, Maritime Networks and their Impact, Rahden, pp. 117-173.

Azuni, M.D. (2015), The Maritime Law of Europe, vol. 1, London.

Cohen, E. (1973), Ancient Athenian Maritime Courts, Princeton-New Jersey.

Couper, A.D. (2005), Historical Perspectives on Seafarers and the Law, [in:] D. Fitzpatrick, M. Anderson (eds.), Seafarers' Rights, Oxford, pp. 3-39. 
Dugan, T.M.P. (2015), From Mid-October to the end of March - voyaging in the medieval Mediterranean, The Journal of MCRI 3, pp. 277-310.

Gaca, A. (2016), Dawne wspólne źródła prawa morskiego stosowane w Europie, Zeszyty Naukowe Wyższej Szkoły Administracji i Biznesu 23, pp. 17-35.

Hong, S.W. [et al.] (1994), Safety Investigation of Noah's Ark in a Seaway, Creation Ex Nihilo, Technical Journal 8.1, pp. 26-35.

Kelly, J.M. (2006), Historia zachodniej teorii prawa, [trans. D. Pietrzyk-Reeves (et al.)], Kraków.

Khalilieh, H. (2006), Admiralty and Maritime Laws in the Mediterranean (ca. 800-1050).

The Kitāb Akriyat al-Sufun vis-à-vis the Nomos Rhodion, Leiden-Boston.

Kotarski, E. (1970), Kto ma państwo morskie... problemy morza w opinii dawnej Polski, Gdańsk.

Koziński, M.H. (2001), Ustawa o bezpieczeństwie morskim, Gdańsk.

Libera, K. (1957), Konsulat Morski wedtug wydania barcelońskiego z 1494 r., Warszawa.

Lindsay, W.S. (1874), History of Merchant Shipping and Ancient Commerce, vol. 1, London.

Łopuski, J. (1982), Ryzyka morskie, [in:] idem (ed.), Encyklopedia podręczna prawa morskiego, Gdańsk, pp. 95-96.

Łopuski, J. (1996), Prawo morskie, vol. 1, Bydgoszcz.

Matysik, S. (1950a), Początki prawa pracy w średniowiecznym prawie morskim, PiP 16, pp. 125-131.

Matysik, S. (1950b), Prawo nadbrzeżne (ius naufragii). Studium z historii prawa morskiego, Toruń.

Matysik, S. (1959), Podręcznik prawa morskiego, Warszawa.

Matysik, S. (1971), Prawo morskie. Zarys systemu, vol. 1, Warszawa.

Osuchowski, W. (1951), Ze studiów nad rzymskim prawem morskim. Uwagi nad zagadnieniem zrzutu morskiego w prawie rzymskim, Czasopismo Prawno-Historyczne 3, pp. 41-52.

Peabody, A.P. (1887), introduction and translation of M.T. Cicero On moral duties, Boston 1887, The Online Library Of Liberty: https://oll.libertyfund.org/titles/cicero-on-moral-duties-de-officiis.

Płodzień, S. (1961), Lex Rhodia de iactu. Studium historyczno-prawne z zakresu rzymskiego prawa handlowo-morskiego, Lublin.

Potter, P. (1924), The Freedom of the Seas in History, Law, and Politics, New York.

Shirop, A., Linden, O. (eds.) (2005), Places of Refuge for Ships Emerging Environmental Concerns of a Maritime Custom, Leiden.

Treves, T. (2015), Historical Development of the Law of the Sea, [in:] D.R. Rothwell, A.G. Oude Elferink, K.N. Scott, T. Stephens (eds.), The Oxford Handbook of the Law of the Sea, Oxford, pp. 1-23.

Zajadło, J. (2017), Sędziowie i niewolnicy. Szkice z filozofii prawa, Gdańsk. 


\section{Justyna Nawrot}

\section{MARITIME SAFETY MODEL ACCORDING TO REGULATIONS IN ANCIENT LAW}

Public maritime law dealing with safety issues is mostly recognised as a contemporary branch of maritime law. In contrast to public maritime law, the history of private maritime law referred to as shipping law is very well described in related literature. But also maritime safety arrangements can be found in the ancient as well medieval collections of laws. Article aims to analyse the ancient roots of contemporary legal institutions referring to maritime safety law. 